\title{
Striatal GPR88 Modulates Foraging Efficiency
}

\author{
Aundrea Rainwater, ${ }^{1}{ }^{\odot E}$ Elisenda Sanz, ${ }^{2}{ }^{\odot}$ Richard D. Palmiter, ${ }^{1}$ and ${ }^{\oplus}$ Albert Quintana ${ }^{1,2}$ \\ ${ }^{1}$ Howard Hughes Medical Institute and Department of Biochemistry, University of Washington, Seattle, Washington 98195, and ${ }^{2}$ Institut de Neurociències i \\ Departament de Biologia Cel·lular, Fisiologia i Immunologia, Universitat Autònoma de Barcelona, Barcelona, Spain
}

The striatum is anatomically and behaviorally implicated in behaviors that promote efficient foraging. To investigate this function, we studied instrumental choice behavior in mice lacking GPR88, a striatum-enriched orphan G-protein-coupled receptor that modulates striatal medium spiny neuron excitability. Our results reveal that hungry mice lacking GPR88 (KO mice) were slow to acquire foodreinforced lever press but could lever press similar to controls on a progressive ratio schedule. Both WT and KO mice discriminated between reward and no-reward levers; however, KO mice failed to discriminate based on relative quantity-reward ( 1 vs 3 food pellets) or effort ( 3 vs 9 lever presses). We also demonstrate preference for the high-reward (3 pellet) lever was selectively reestablished when GPR88 expression was restored to the striatum. We propose that GPR88 expression within the striatum is integral to efficient action-selection during foraging.

Key words: action selection; decision making; mouse genetics; striatum

\section{Significance Statement}

Evolutionary pressure driving energy homeostasis favored detection and comparison of caloric value. In wild and laboratory settings, neural systems involved in energy homeostasis bias foraging to maximize energy efficiency. This is observed when foraging behaviors are guided by superior nutritional density or minimized caloric expenditure. The striatum is anatomically and functionally well placed to perform the sensory and motor integration necessary for efficient action selection during foraging. However, few studies have examined this behavioral phenomenon or elucidated underlying molecular mechanisms. Both humans and mice with nonfunctional GPR88 have been shown to present striatal dysfunctions and impaired learning. We demonstrate that GPR88 expression is necessary to efficiently integrate effort and energy density information guiding instrumental choice.

\section{Introduction}

Lesion and anatomical study has led to the hypothesis that the basal ganglia participates in an action-selection network (DennyBrown and Yanagisawa, 1976; Mink, 1996; Redgrave et al., 1999; Gurney et al., 2001; Houk et al., 2007). Within this network, the striatum has unique potential to influence movement through widespread cortical input and output to pallido-thalamocortical pathways (Alexander and Crutcher, 1990; Hoover and Strick,

Received July 30, 2016; revised June 8, 2017; accepted June 14, 2017.

Author contributions: A.R., R.D.P., and A.Q. designed research; A.R., E.S., and A.Q. performed research; A.R. and A.Q. analyzed data; A.R., R.D.P., and A.Q. wrote the paper.

This work was supported by Marie Skłodowska-Curie Action H2020-MSCA-IF-2014-658352 to E.S., Ramón y Cajal Fellowship RyC-2012-11873 to A.Q., European Research Council Starting Grant NEUROMITO ERC-2014-StG-638106, to A.Q., and MINECO Proyectos I+D de Excelencia SAF2014-57981P to A.Q. We thank Scott Evans for helpful discussion on experimental design and assistance with med pc programming; Katherine Kafer for assistance with surgery; Glenda Froelick and Elyse Allen for assistance with histology; Rod Meneses for animal care; and Ali Güler and Roser Nadal for helpful discussion and assistance.

The authors declare no competing financial interests.

Correspondence should be addressed to Dr. Albert Quintana, Institut de Neurociències i Departament de Biologia

Cellular, Fisiologia i Immunologia, Universitat Autònoma de Barcelona, Facultat de Medicina, M1/113, 08193 Bellaterra, Spain. E-mail: albert.quintana@uab.cat.

DOI:10.1523/JNEUROSCI.2439-16.2017

Copyright $\odot 2017$ the authors $\quad 0270-6474 / 17 / 377939-09 \$ 15.00 / 0$
1993). It also receives dopaminergic signals conveying information about relative nutrient density, reinforcement probability, delay, and effort to acquire reinforcement (Fiorillo et al., 2003; Denk et al., 2005; Tobler et al., 2005; Cagniard et al., 2006; Norgren et al., 2006; Roesch et al., 2007; Fiorillo et al., 2008; Kobayashi and Schultz, 2008; Van den Heuvel and Pasterkamp, 2008; Beeler et al., 2010; Gan et al., 2010).

In humans, monetary selection based on positive and negative quantity integration has been measured using the Iowa Gambling Task (Bechara et al., 1994). Humans suffering from pathologies or disorders affecting the basal ganglia demonstrate disadvantageous choice behavior on this test (Grant et al., 2000; Bechara et al., 2001; Clark et al., 2001; Stout et al., 2001; Whitney et al., 2004; Shurman et al., 2005; Malloy-Diniz et al., 2007; Barry and Petry, 2008; Struglia et al., 2011; Buelow et al., 2014). In a rodent task modeled after the Iowa Gambling Task, hyperdopaminergic mice failed to acquire nutritionally profitable preferences (Young et al., 2011). Consistent with these results, single-unit recordings from rat striatum demonstrate both movement specificity and reward-value encoding (Stalnaker et al., 2010). In rats choosing between probabilistic food rewards, striatal neuron activity was predictive of upcoming action selection and value (Kim et al., 
A

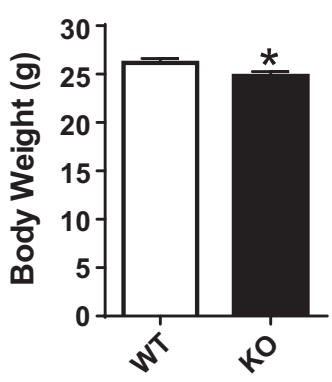

B

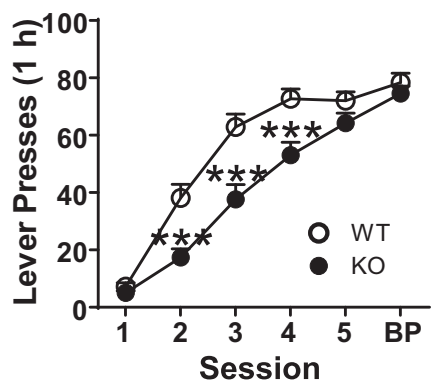

C

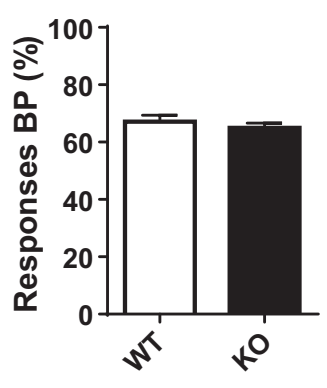

D

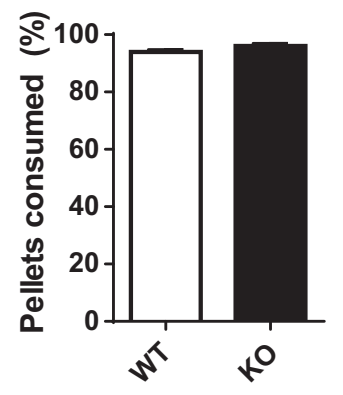

Figure 1. K0 mice made fewer lever presses early in lever press training (FR1, alternating, no-choice). $A$, K0 mice $(n=31)$ presented a slight decrease in body weight compared with WT ( $n=29)$ mice. $\boldsymbol{B}, \mathrm{KO}$ mice made fewer responses early in lever press training. $\boldsymbol{C}$, Percent responses allocated to the preferred lever did not differ between K0 and WT mice during BP session (all choice trials). D, Percent food pellets consumed did not differ between K0 and WT mice (cumulative, Sessions 1-5, and BP). ${ }^{*} p<0.05,{ }^{* * *} p<0.001$ vs WT.

2009). In addition, pharmacological or genetic manipulations that impact the striatum also appear to alter effort- and reinforcement value-based response selection (Salamone et al., 1994, 2001; Caul and Brindle, 2001; Cagniard et al., 2006; Font et al., 2008).

In the present study, we investigated the role of the striatum during decision making based on nutritional density and effort in hungry mice lacking GPR88. GPR88 is an orphan GPCR that is especially abundant in the striatum (Mizushima et al., 2000; Massart et al., 2009; Quintana et al., 2012). Humans harboring nonsense mutations in GPR88 present with motor alterations and learning disabilities (Alkufri et al., 2016). GPR88 is expressed by both dopamine receptor Type 1and Type 2-expressing medium spiny projection neurons (MSNs), where it is primarily localized to dendritic spines and associated with vGlut1-positive synapses (Mizushima et al., 2000; Ghate et al., 2007; Logue et al., 2009; Massart et al., 2009; Van Waes et al., 2011; Quintana et al., 2012). Mice lacking Gpr88 (Gpr88 $8^{\mathrm{Cre} / \mathrm{Cre}}$ or KO mice) display higher firing rates and increased sensitivity to cortical stimulation in MSNs (Quintana et al., 2012). GPR88 KO mice exhibit dark phase hyperactivity, hypersensitivity to novelty (environment, object), reduced anxiety (elevated-plus maze, marble burying, novelty-suppressed feeding), and impairments on rotarod and active-avoidance assays; some phenotypes have been linked to striatal GPR88 (Quintana et al., 2012; Meirsman et al., 2016a, b). In the present study, we examined the contribution of striatal GPR88 in instrumental choice behavior based on nutritional density and effort.

\section{Materials and Methods}

Animals. All experiments were approved by the University of Washington Institutional Animal Care and Use Committee. Mice were generated by replacing the Gpr88 coding region with a Cre recombinase cassette (Quintana et al., 2012). Male Gpr $88^{\mathrm{Cre} / \mathrm{Cre}}$ (KO) and $\mathrm{Gpr}^{\mathrm{O} 88^{+/+}}$littermates (WT) were generated crossing Gpr $88^{\mathrm{Cre} /+}$ heterozygotes that had been backcrossed to C57BL/6 mice for $>10$ generations. Mice were $\sim 12$ weeks of age at instrumental conditioning start. Mice were $6-13$ weeks of age at food intake measure start. Viral injection surgeries were performed at $\sim 10$ weeks of age. For instrumental conditioning, mice were individually housed for $3 \mathrm{~d}$, then gradually food restricted to $\sim 85 \%$ ad libitum body weight for $7 \mathrm{~d}$ before test start. For food intake measure, mice were individually housed for $5 \mathrm{~d}$ before test start. Instrumental conditioning
B
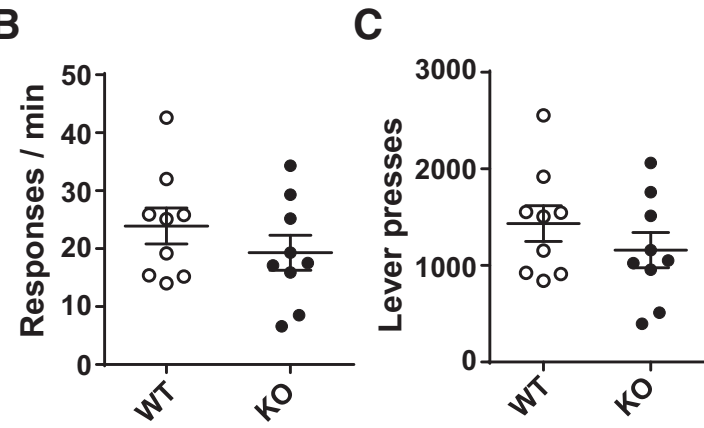

and food intake measure were performed from 3:00 to 7:00 P.M. in the light phase of the $12 \mathrm{~h}$ light/dark cycle. Water was available at all times in the home cage, and daily food rations (standard rodent chow) were provided at the end of each daily instrumental conditioning session.

Instrumental conditioning apparatus. For behavioral experiments, standard mouse operant chambers (model ENV-300, Med Associates) equipped with fans and housed in sound-attenuating chambers were used. Operant chambers were equipped with two retractable levers separated by a central food receptacle equipped with an infrared head-entry detector. MED-PC IV (Med Associates) software was used to control the apparatus and record lever presses and head entries; $20 \mathrm{mg}$ rodent purified diet food pellets (Dustless Precision Pellets, Bio-Serv; $3.60 \mathrm{kcal} / \mathrm{g}$ ) were used as reinforcement. Uneaten pellets left in the food hopper were counted at the end of each session.

Lever press acquisition. Daily lever press training sessions lasted for $1 \mathrm{~h}$ or until 100 lever presses were made. Mice initiated each trial by head entry into the food hopper, which elicited lever extension. For Sessions $1-5$, one lever was presented at a time (no choice) in a pseudo-random pattern with presentation number approximately balanced for right and left levers. A lever press elicited lever retraction, delivery of 1 food pellet into the food hopper, and a $1 \mathrm{~s}$ intertrial interval. For Sessions 1-4, noncontingent reward pellets were delivered on a variable interval $1 \mathrm{~min}$ schedule for the first $15 \mathrm{~min}$; noncontingent reward delivery coincided with a brief extension/retraction of both levers. A bias probe (BP) session was administered on training day 6 in which both levers were presented during each trial (choice). After $6 \mathrm{~d}$ of lever press training, mice were distributed into cohorts for each instrumental choice assay. The lever that received the highest number of responses during the BP session was selected as the progressive ratio (PR) lever or low-value lever (1 pellet; FR9) for two-lever choice.

$P R$. After lever press acquisition training, one group of mice was tested on a one-lever, nonarithmetic PR schedule, as described previously (Robinson et al., 2007). PR responding was measured during a single time-constrained $(1 \mathrm{~h})$ session. 


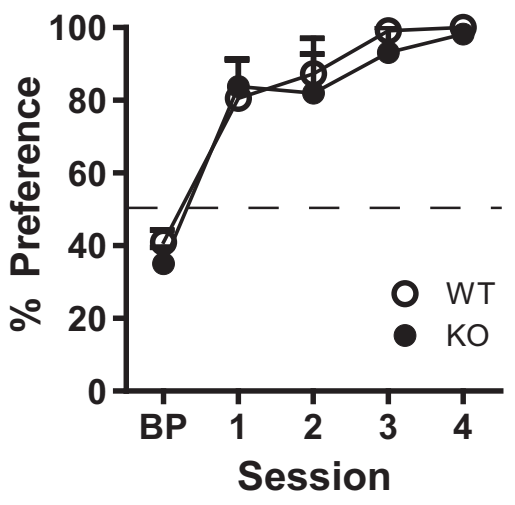

Figure 3. K0 mice discriminated between levers based on reward omission (1 pellet vs 0 ). K0 $(n=6)$ and WT ( $n=6)$ mice acquired preference for the rewarded lever. Percent preference was calculated from responses made during choice trials (Block 2). Percent preference $=$ no. of responses on 1 pellet lever/total no. of responses on both levers.
2013). All groups received viral injections at multiple coordinates (rostral injection sites: from bregma, anteroposterior $=1.2 \mathrm{~mm}$, mediolateral $=$ $\pm 1.5 \mathrm{~mm}$, dorsoventral $=-3.25 \mathrm{~mm} /-3.75 \mathrm{~mm}$; caudal injection sites: from bregma, anteroposterior $=0 \mathrm{~mm}$, mediolateral $= \pm 2.25 \mathrm{~mm}$, dorsoventral $=-3.25 \mathrm{~mm} /-3.75 \mathrm{~mm}$ ) to produce widespread transduction of the striatum. The expression of mCherry or tdTomato in the striatum was examined at the end of behavioral testing in sections of the striatum to determine degree of viral expression and injection placement. Only mice with $\sim 45 \%$ transduction of total striatal area (detailed below) were included in behavioral analysis. These parameters were selected based on our previous validation of the injection coordinates and Gpr88 striatal restoration after viral transduction (Quintana et al., 2012).

Histology. Mice were anesthetized by pentobarbital overdose (Beuthanasia-D, $200 \mathrm{mg} / \mathrm{kg}$, i.p.) and subsequently perfused as described previously (Quintana et al., 2012). Brains were dissected and postfixed in 4\% PFAPBS solution for $16 \mathrm{~h}$. Finally, brains were cryoprotected in $30 \%$ sucrosePBS for $24 \mathrm{~h}$, frozen in dry ice, and stored at $-80^{\circ} \mathrm{C}$. The $30-\mu \mathrm{m}$-thick sections were obtained using a cryostat. To quantify the degree of viral transduction, the ratio of fluorescent area/total striatal area was calculated in alternate striatal sections $(60 \mu \mathrm{m}$ apart) using ImageJ software.

Statistics. Statistical analysis was performed using Prism GraphPad software. Appropriate tests were selected according to experimental design. Tests used, statistics, and significance are stated throughout the text.
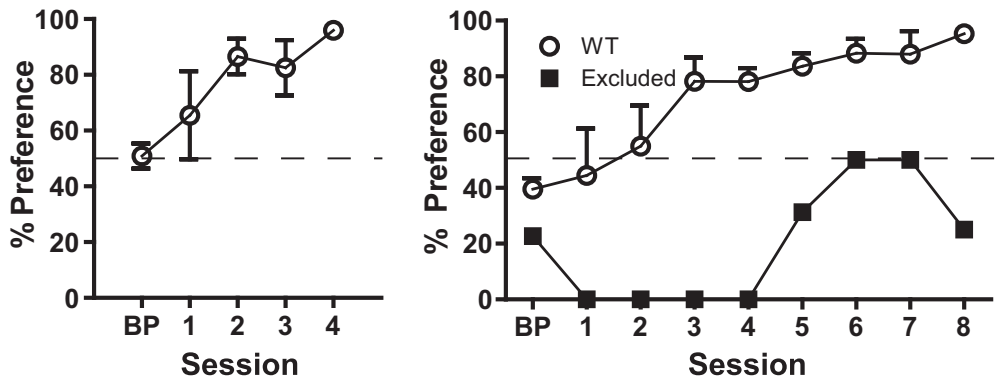

Figure 4. Contingency-independent lever bias developed when response outcomes were equal and rarely when they differed. $\boldsymbol{A}$, C57BL/6 mice $(n=5)$ form a clear (contingency-independent) bias when both levers delivered one pellet. $\boldsymbol{B}$, Most WT mice (circles, $n=4$ ) acquired preference for the high-reward (3 pellet) lever. One subject ( 1 of 5 ) persisted in preference for the less profitable (1 pellet) lever (contingency-independent bias) (squares, $n=1$ ). Percent preference was calculated from responses made during choice trials (Block 2). Percent preference $=$ no. of responses on 1 pellet lever/total no. of responses on both levers.

Two-lever discrimination testing. After lever press acquisition training, three cohorts of mice were tested on three two-lever choice paradigms. Each two-lever choice session lasted $1 \mathrm{~h}$ and was divided into two $30 \mathrm{~min}$ blocks. During the first block, mice received only training trials in which one lever was presented per trial (no choice), in a pseudo-random order with approximately equal presentations of each lever. During the second block, mice received only choice trials in which both levers were presented each trial and lever preference could be measured. Both training and choice trials were initiated by a head entry into the food hopper, which elicited lever extension. A lever press initiated reward delivery and the start of a $90 \mathrm{~s}$ intertrial interval. This longer intertrial interval period limited the number of trials a mouse could complete per block to $\sim 20$ trials and allowed sufficient time for reward retrieval and consumption. Reinforcement schedule (food pellets earned) was static for all trials/sessions.

Twenty-four hour food intake: concurrent choice. One cohort of naive WT and KO mice was tested for consumption of two novel chows presented concurrently. At test start, mice were weighed, food in the hopper withdrawn, and two preweighed biscuits (per two novel test chows; $\sim 20$ g per chow type) added to the cage floor. Chow weights were recorded and fresh rations supplied every $24 \mathrm{~h}$ for $3 \mathrm{~d}$. Bio-Serv Rodent Diet F3028 (3.35 kcal/g) and Bio-Serv Rodent Diet AIN-93G/ F3156 (3.74 $\mathrm{kcal} / \mathrm{g}$ ) were used as novel test chows (Bio-Serv).

Viral restoration of Gpr88 expression to the striatum. An adenoassociated viral vector (AAV) with a Cre-dependent cassette encoding a human floxed-stop (fs) hGPR88-TdTomato fusion protein was injected into KO or WT mice as described previously (Quintana et al., 2012). Sham-injected KOs (vKOs) received an injection of a Cre-dependent viral vector expressing mCherry (AAV-DIO-mCherry) (Carter et al.,

\section{Results \\ Lack of Gpr88 delays lever press acquisition} for food on an FR1 schedule where lever presentation alternated between two levers (no choice). Baseline body weight was measured before food restriction at $\sim 12$ weeks of age (Fig. $1 A$ ). When data from all mice that underwent instrumental conditioning were pooled, $\mathrm{KO}$ mice weighed significantly less than WT littermates (Student's $t$ test, unpaired, twotailed, $\left.t_{(58)}=2.077, p=0.042\right)$. KO mice also made significantly fewer lever presses early in training (Sessions 2-4; Fig. $1 B$ ) (significant effect of genotype, $F_{(1,58)}=12.74$, $p<0.001$ by two-way repeated-measures ANOVA; Bonferroni post hoc, effect of session, $F_{(5,290)}=209.4, p<0.001$, Bonferroni post hoc test, $p<0.001$, interaction genotype $\times$ session, $F_{(5,290)}=$ $7.00, p<0.001)$. For the last two training sessions, however, response number did not significantly differ between WT and KO groups. WT and $\mathrm{KO}$ mice did not differ in percent responses made on the preferred lever (received the most presses) during the BP session (all choice trials; Fig. 1C; Student's $t$ test, unpaired, two-tailed, $\left.t_{(58)}=0.7800, p=0.439\right)$. WT and KO mice consumed $>90 \%$ of the total rewards earned during lever press training Sessions 1-5 (Fig. 1D; Student's $t$ test, unpaired, two-tailed, $\left.t_{(58)}=1.722, p=0.095\right)$.

\section{PR is unaffected by GPR88 deficiency}

Upon completion of lever press training, responses made during a $1 \mathrm{~h}$ PR session were measured in one cohort of WT and KO mice. Mean rewards earned (ratios completed) did not differ significantly between WT and KO groups (Fig. 2A; Student's $t$ test, unpaired, two-tailed, $\left.t_{(16)}=1.155, p=0.265\right)$. WT and $\mathrm{KO}$ mice also did not differ significantly in lever press speed (Fig. 2B; Student's $t$ test, unpaired, two-tailed, $t_{(16)}=1.065, p=0.302$ ) or
Hungry mice were trained to lever press 
total lever presses made (Fig. 2C; Student's $t$ test, unpaired, two-tailed, $t_{(16)}=$ $1.061, p=0.304)$.

\section{Lever selection based on reward omission is unaffected by GPR88 deficiency}

Upon completion of lever press training, one cohort of WT and KO mice was tested on a two-lever choice paradigm in which one lever did not elicit reward delivery (reward omitted). WT and KO mice did not differ in the percentage of total responses made on the rewarded lever (choice trials; Block 2) (Fig. 3; two-way, repeatedmeasures ANOVA, effect of genotype: $F_{(1,10)}=0.351, p=0.566$, effect of session: $F_{(4,40)}=30.09, p<0.001$, interaction genotype $\times$ session: $F_{(4,40)}=0.20, p=$ $0.938)$.

\section{Contingency-independent lever bias}

Two-lever choice assay was initially characterized with small cohorts of pure C57BL/6 mice. Upon completion of lever press training, one cohort was tested under conditions where both levers were reinforced on an FR1 schedule. Despite equivalent response outcome, mice exhibited a significant lever preference during choice trials (Fig. $4 A$; one-way repeated-measures ANOVA, effect of session: $\left.F_{(4,16)}=7.78, p<0.01\right)$. Because reinforcement schedule was the same for both levers, reward contingency could not account for preference.

A second small cohort of C57BL/6 mice was tested under conditions where response outcome differed: one lever elicited delivery of 3 pellets and the opposite, 1 pellet. Despite the marked contrast in food reward, 1 in 5 mice preferred the low-value lever (Fig. 4B). This performance profile was used to generate exclusion criterion $(>80 \%$ preference for low-value lever by day 4 and $>2$ SDs from the mean by day 8) for outliers that displayed a contingencyindependent bias in tests performed later with GPR88 KO mice and WT littermate controls. The majority of mice (4 of 5) formed a significant preference for the 3-pellet lever (Fig. 4; one-way, repeated-measures ANOVA, effect of session: $F_{(8,24)}=$ $6.16, p<0.001)$.

\section{GPR88 deficiency impairs lever selection based on reward density}

Upon completion of lever press training, one cohort of WT and $\mathrm{KO}$ mice was tested on a two-lever choice assay in which responses on one lever delivered 3 pellets and responses on the opposite lever delivered 1 pellet. The majority of WT mice ( 8 of 10) developed a behavioral profile where the high-reward lever (3 pellet) was selected most often (Fig. 5A). Two WT mice selected the lever favored during the BP session (two-way repeatedmeasures ANOVA, effect of lever preference: $F_{(1,8)}=48.06, p<$ 0.001, effect of session: $F_{(8,64)}=2.452, p<0.05$, interaction genotype $\times$ session: $F_{(8,64)}=6.789, p<0.01, p<0.001$, Bonferroni post-test). These mice were excluded as outliers from the group mean. The performance profile of KO mice as a group prevented similar exclusions (Fig. $5 B$ ). Including all 10 subjects, $\mathrm{KO}$ mice allocated significantly fewer responses to the 3-pellet lever (Fig. 5C; two-way repeated-measures ANOVA, effect of genotype: $F_{(1,16)}=5.58, p<0.05$, effect of session: $F_{(8,128)}=12.60$, $p<0.001$, interaction genotype $\times$ session: $F_{(8,128)}=3.62, p<$ $0.001)$. KO mice also completed significantly fewer no-choice (Block 1) trials early in training (Fig. 5D; Block 1: two-way, repeated-measures ANOVA, effect of genotype: $F_{(1,16)}=1.965$, $p=0.180$; Block 2). There were no significant differences between WT and $\mathrm{KO}$ mice in number of choice trials completed (Fig. 5E; Block 2: two-way repeated-measures ANOVA, effect of genotype: $\left.F_{(1,16)}=0.031, p=0.862\right)$, or rewards consumed (Fig. 5F; unpaired $t$ test, two-tailed: $t_{(16)}=1.762, p=0.0972$ ).

\section{GPR88 deficiency impairs lever selection based on effort}

Upon completion of lever press training, one cohort of WT and $\mathrm{KO}$ mice was tested on a two-lever choice assay in which both levers delivered one pellet; one lever elicited reward delivery after 3 lever press responses (FR3) and the opposite after 9 (FR9). KO mice allocated significantly fewer responses to the FR3 (loweffort) lever compared with the WT group (Fig. 6A; two-way repeated-measures ANOVA, effect of session: $F_{(3,30)}=12.39 ; p<$ 0.001; effect of genotype: $F_{(1,10)}=5.994, p=0.034$, Bonferroni 


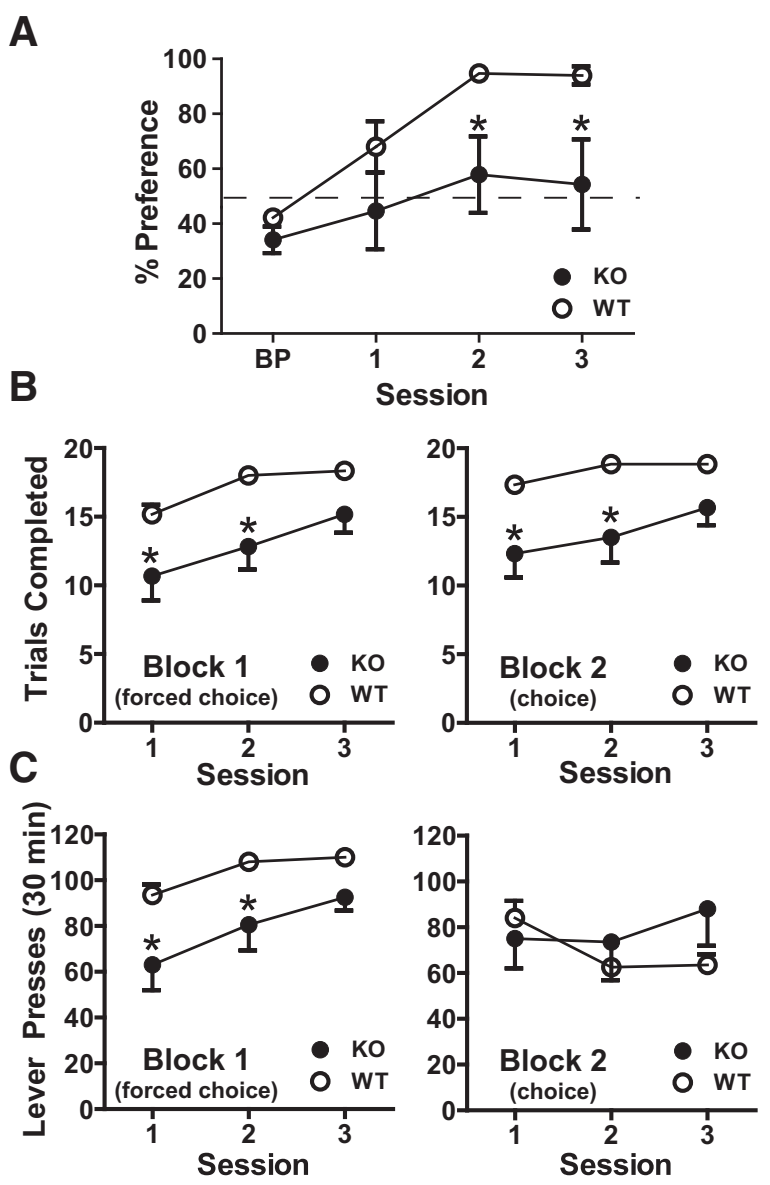

Figure 6. K0 mice failed to discriminate based on effort density. $A$, WT mice $(n=6)$ readily shifted responding to the low-effort (FR3) lever. KO mice $(n=6)$ chose FR3 and FR9 levers at similar frequency. $\boldsymbol{B}, \mathrm{KO}$ mice completed fewer trials for both blocks (no-choice, choice). KO mice performed the same number of responses during choice trials $(\boldsymbol{C})$ but earned fewer rewards (trials completed) for their efforts. Percent preference was calculated from responses made during choice trials (Block 2). Percent preference $=$ no. of responses on FR3 lever/total no. of responses on both levers. ${ }^{*} p<0.05$ vs WT.

post-test, $p<0.05$ vs WT; interaction genotype $\times$ session: $F_{(3,30)}=$ 2.05, $p=0.128$ ). KO mice completed fewer trials (earned fewer rewards) during no-choice trials (Block 1) (Fig. 6B; two-way repeated-measures ANOVA, effect of genotype: $F_{(1,10)}=7.832$ $p=0.020, p<0.05$, Sidak's post-test, $p<0.05$ vs WT; effect of session: $F_{(2,20)}=23.37, p<0.001$; interaction genotype $\times$ session: $\left.F_{(2,20)}=1.60, p=0.227\right)$ and made significantly fewer lever presses (Fig. 6C; two-way repeated-measures ANOVA, effect of genotype: $F_{(1,10)}=8.30, p<0.05$, Sidak's post-test, $p<0.05$ vs WT; effect of session: $F_{(2,20)}=14.42, p<0.001$; interaction genotype $\times$ session: $\left.F_{(2,20)}=1.20, p=0.322\right)$. During choice trials (Block 2), KO mice earned fewer rewards during the first two sessions (Fig. 6B; two-way repeated-measures ANOVA, effect of genotype: $F_{(1,10)}=8.52, p=0.0153$, Sidak's post-test, $p<$ 0.05 vs WT; effect of session: $F_{(2,20)}=8.94, p=0.002$, interaction genotype $\times$ session: $\left.F_{(2,20)}=2.08, p=0.152\right)$. However, WT and $\mathrm{KO}$ did not differ in total lever presses performed (Fig. 6C; two-way repeated-measures ANOVA, effect of genotype: $F_{(1,10)}=0.33, p=0.5772$; effect of session: $F_{(2,20)}=3.11, p=0.067$; interaction genotype $\times$ session: $\left.F_{(2,20)}=6.42, p=0.007\right)$, suggesting that $\mathrm{KO}$ mice did not differ from WT littermates in motor performance on this test.
Nutrient density discrimination is unaffected by GPR88 deficiency

Following acclimation to individual housing, one naive cohort of WT and KO mice was presented with two novel chows differing in energy density. Chow consumption was measured every $24 \mathrm{~h}$ for $3 \mathrm{~d}$. Both WT and KO mice selectively consumed $>80 \%$ of calories from the chow higher in energy density (3.74 vs 3.35 $\mathrm{kcal} / \mathrm{g}$; Fig. 7A; two-way repeated-measures ANOVA, effect of genotype: $F_{(1,12)}=0.151, p=0.705$; effect of test day: $F_{(2,24)}=$ 2.646, $p=0.092$, interaction genotype $\times$ session: $F_{(2,24)}=0.67$, $p=0.522)$. KO mice consumed significantly more calories selectively from the energy-dense chow (Fig. 7B; two-way repeatedmeasures ANOVA, effect of genotype: $F_{(1,12)}=7.149, p=0.020$; effect of test day: $F_{(2,24)}=18.210, p<0.001$, interaction genotype $\times$ session: $\left.F_{(2,24)}=0.588, p=0.563\right)$. There were no significant differences between WT and $\mathrm{KO}$ groups in calories consumed from the chow of inferior energy density (Fig. 7B; two-way repeated-measures ANOVA, effect of genotype: $F_{(1,12)}=0.013, p=0.911$; effect of test day: $F_{(2,24)}=0.941, p=0.404$, interaction genotype $\times$ session: $\left.F_{(2,24)}=1.01, p=0.379\right)$. KO mice consumed significantly more total calories during the first $2 \mathrm{~d}$ of testing, consistent with a hypersensitivity to novelty (Fig. 7C; two-way repeated-measures ANOVA, effect of genotype: $F_{(1,12)}=6.070, p=0.030$; effect of test day: $F_{(2,24)}=32.38, p<0.0001$, interaction genotype $\times$ session: $\left.F_{(2,24)}=1.653, p=0.212\right)$.

\section{Striatal GPR88 restoration in KO mice rescues lever press acquisition}

Gpr88 expression was restored to the dorsal striatum of $\mathrm{KO}$ mice by viral transduction with a vector encoding a GPR88-tdTomato fusion protein (AAV1-fs-GPR88-TdTomato, virally restored [vrKO] mice; Fig. 8A). As controls, WT and KO littermates received four injections of a virus expressing tdTomato or mCherry only (AAV1-tdTomato, AAV-DIO-mCherry, vWT mice, vKO mice, respectively). Body weight was measured 1 week following viral-injection surgery; vKO mice weighed significantly less than both control groups (Fig. $8 B$; one-way ANOVA, two-tailed, $F_{(2,29)}=$ $4.083, p=0.027$, Tukey's post-test, $p<0.05$ ). Two weeks following surgery, mice were trained to lever press. Control vKO mice made significantly fewer lever presses during response acquisition training. $\mathrm{KO}$ mice with striatal GPR88 restored (vrKO) did not differ from vWT controls (Fig. 8C; two-way repeated-measures ANOVA, effect of genotype: $F_{(2,29)}=4.483, p=0.020$, effect of session: $F_{(5,145)}=142.9, p<0.001$, interaction genotype $\times$ session: $\left.F_{(10,145)}=2.201, p=0.021\right)$. All groups allocated the same percent responses to the preferred lever during $\mathrm{BP}$ (all choice trials) (Fig. $8 D$; one-way ANOVA, two-tailed, $F_{(2,29)}=0.169, p=$ $0.845)$. There were no differences between groups in percent pellets consumed during lever press acquisition training (cumulative days $1-5$ ) (Fig. $8 E$; one-way ANOVA, two-tailed, $F_{(2,29)}=$ $1.038, p=0.367)$.

\section{Striatal GPR88 restoration in KO mice rescues lever selection} based on reward density

Upon completion of lever press training, one cohort of mice that received viral injection was tested on reward density choice assay ( 3 pellets vs 1 pellet). Control vKO mice allocated significantly fewer responses to the 3-pellet lever; both vWT and vrKO groups shifted responding to the high-reward lever (Fig. 9A; two-way repeated-measures ANOVA, effect of genotype: $F_{(2,19)}=11.17$, $p<0.001$; Tukey's post-test, $p<0.05, p<0.01$ vs WT, effect of session: $F_{(8,152)}=3.515, p<0.001$; interaction genotype $\times$ session: $\left.F_{(16,152)}=2.430, p=0.003\right)$. All groups completed a 
similar number of training (Block 1; nochoice) trials (Fig. 9B; two-way repeatedmeasures ANOVA, effect of genotype: $F_{(2,19)}=1.236, p=0.313$; effect of session: $F_{(7,133)}=11.25, p<0.001$; interaction genotype $\times$ session: $F_{(14,133)}=0.658, p=$ $0.811)$. vrKO mice completed significantly more choice (Block 2) trials (Fig. 9C; two-way repeated-measures ANOVA, effect of genotype: $F_{(2,19)}=4.253, p=0.030$; Tukey's post-test $p<0.05 \mathrm{vs} \mathrm{WT,} \mathrm{effect} \mathrm{of}$ session: $F_{(7,133)}=6.874, p<0.001$; interaction genotype $\times$ session: $F_{(14,133)}=$ $1.227, p=0.263)$. A slight, but significant, increase in percent pellets consumed was seen for both vKO and vrKO groups (cumulative, days 1-8) (Fig. 9D; KruskalWallis test, $\mathrm{H}_{(2)}=9.338, p=0.009$, Dunn's post-test, $p<0.05$ ).

\section{Discussion}

Our results demonstrate that inactivation of the Gpr88 gene impaired food-reinforced action selection. In the present study, KO mice failed to shift instrumental responses when guided by either nutritional density (1 pellet vs 3 pellets) or effort (FR3 vs FR9). Although body weight was slightly reduced in $\mathrm{KO}$ mice, preference for energy-dense chow and performance on PR were intact. However, when asked to obtain food by lever press, hungry KO mice were slower to learn than WT littermates.

Impaired motor coordination has been demonstrated in $\mathrm{KO}$ mice (Quintana et al., 2012; Meirsman et al., 2016a, b) and humans harboring GPR88 mutation (Alkufri et al., 2016). In the present study, however, WT and KO mice did not differ in lever press speed or total lever presses during PR. Our results are consistent with a recent report that forelimb strength and motor coordination are intact in GPR88 KO mice (Meirsman et al., 2016b). Impaired $\mathrm{KO}$ instrumental performance profiles (fewer lever presses early in training, fewer completed trials during effort density choice assay) are thus not attributable to inability to perform instrumental response. KO mice also did not acquire preference for the low-effort lever (FR3) during choice trials. Both results likely reflect failure to detect and/or adapt to changes in response requirement, consistent with dysregulated sensorimotor gating linked to GPR88 deficiency (Logue et al., 2009).

Despite impaired effort discrimination, both WT and KO mice readily responded to omission of food reinforcement (1 pellet vs 0 pellets). This supports the view that $\mathrm{KO}$ mice detect nutrition and readily extinguish responding when nutritional reinforcement is withheld. KO mice were impaired, however, when asked to discriminate between responses differing in nutrient density (1 pellet vs 3 pellets). KO mice did not acquire a preference for the high-reward lever as did most WT mice. This may reflect failure to integrate energy density signals (midbrain dopamine) and action value.

In a second set of experiments, we asked whether selective restoration of GPR 88 gene expression could restore efficient choice behavior in $\mathrm{KO}$ mice. Indeed, $\mathrm{KO}$ mice with GPR 88 restored to the dorsal striatum (vrKO) shifted responses to a 3-pellet lever (1-pellet vs 3-pellet choice assay) similar to vWT controls. However, KOs that received control virus (mCherry; vKO) chose the 3-pellet lever significantly fewer times. This suggests that GPR88 expression within the dorsal striatum is sufficient to support action selection based on energy density. Although GPR88 is expressed
B
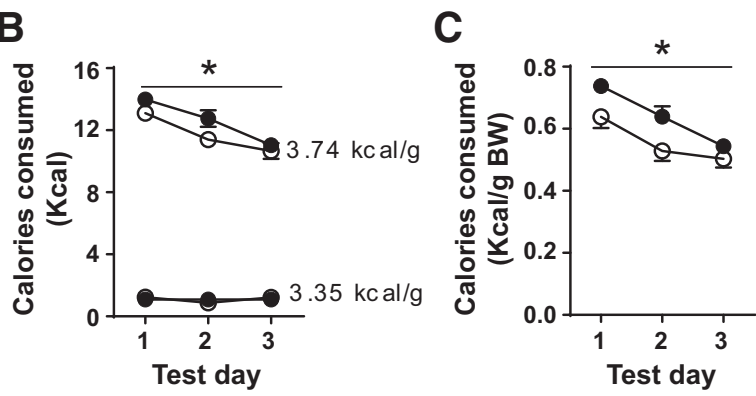

Figure 7. WT $(n=6)$ and KO mice $(n=8)$ readily discriminated chow energy density when two novel chows were presented choms. $\boldsymbol{B}$, KO mice consumed significantly more calories, selectively from chow of superior energy density; no differences were observed in calories consumed from chow of inferior energy density. $C, K O$ mice consumed more total calories for the first $2 \mathrm{~d}$ (kcal/g body weight). ${ }^{*} p<0.05$ vs WT.

in numerous brain regions, including cortex, globus pallidus, and amygdala (Mizushima et al., 2000; Becker et al., 2008; Ingallinesi et al., 2015; Massart et al., 2016), results here are consistent with previous data demonstrating a prominent role for striatal GPR88 in the phenotype of Gpr88KO mice (Quintana et al., 2012; Meirsman et al., 2016a).

Virally treated GPR88 KO mice (either vrKO or vKO mice) consumed significantly more reward pellets than virally treated WT control mice. When presented with two novel chows, GPR88 KO mice selectively consumed more calories from chow of superior energy density. It has been reported that opiate agonist infusion into ventral striatum elicits increases in food intake and selective consumption of energy-dense chow under choice conditions (Zhang et al., 1998; Zhang and Kelley, 2000; Kelley, 2004). In the present study, viral restoration was targeted to the dorsal striatum and the resulting viral expression relatively absent from ventral striatum. It is, at present, unclear how alterations in ventral striatal function may have contributed to phenotypes resulting from GPR88 KO or its viral restoration to dorsal striatum.

In the classic view of basal ganglia function, direct and indirect pathways collaborate to execute goal-directed behavior and suppress conflicting activity (Alexander and Crutcher, 1990). Within this circuit, neural inputs are thought to compete for influence over descending motor resources (Gurney et al., 2001). Concurrent with cortical input, dopamine neurons provide significant input to the striatum and encode relative nutritional density (Hajnal et al., 2004; Roesch et al., 2007; Gan et al., 2010). Calcium imaging of these dopaminergic fibers has demonstrated predictive encoding of upcoming lever selections in mice choosing between probabilistic sucrose rewards (Parker et al., 2016). Downstream of these signals, striatal output may be segregated according to cost (energy expenditure) and gain (energy density) via D1 or D2 pathways (Schultz, 2010). Consistent with this view is the observation that optogenetic activation of the D1 pathway promotes movement, whereas activation of D2 MSNs suppresses it (Kravitz et al., 2010). Recent findings indicate that both D1 and D2 pathways participate in the initiation of action (Cui et al., 2013; Tecuapetla et al., 2016; Vicente et al., 2016).

GPR88 is expressed in both D1- and D2-expressing MSNs (Massart et al., 2009; Quintana et al., 2012) and constitutively regulates the excitability in both populations (Quintana et al., 2012). Although GPR88's signaling mechanism remains unknown, it likely modulates opioid ( $\delta$ and $\mu$ ), dopaminergic, glutamatergic, and GABAergic receptor signal transduction (Befort et al., 2008; Logue et al., 2009; Quintana et al., 2012; Meirs- 
A

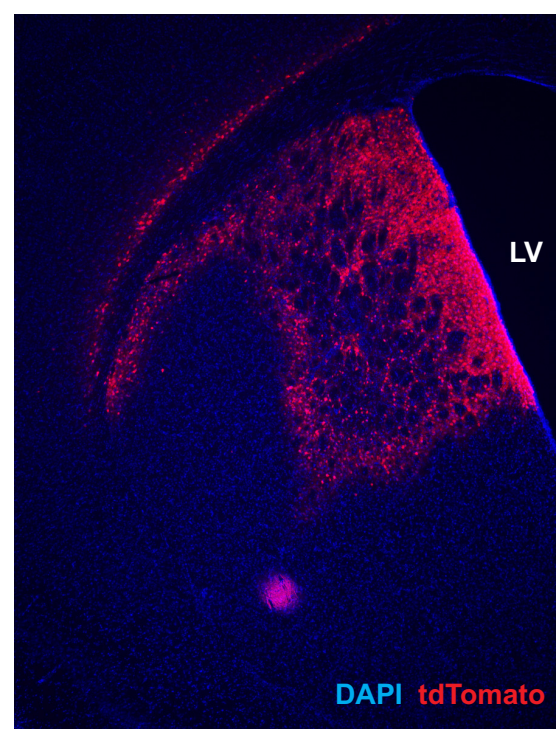

B
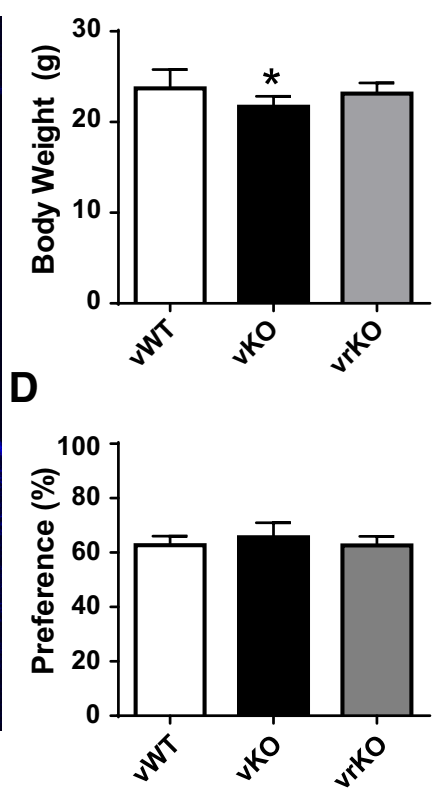

C

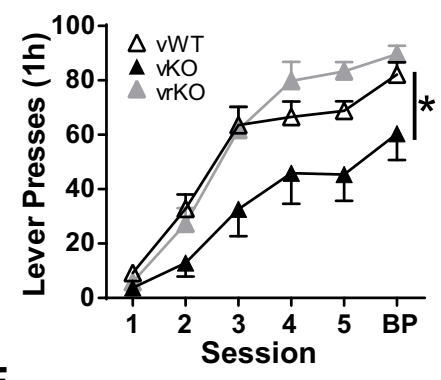

E

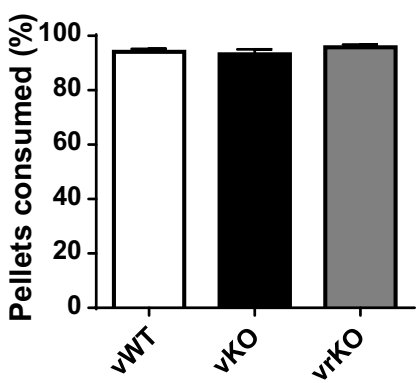

Figure 8. Viral restoration of GPR88 expression to the striatum restored performance during lever press training (FR1, alternating lever presentation Sessions $1-5)$. $A$, Representative image of the degree of transduction after viral GPR88 reexpression. Red represents tdTomato. Blue represents DAPI. LV, Lateral ventricle. $\boldsymbol{B}$, Baseline body weight was diminished in K0 mice that received control viral injection (vKO, $n=8$ ). C, These mice made fewer responses during lever press training. K0 mice with GPR88 expression virally restored to the striatum (vrK0, $n=12$ ) acquired the lever press response similar to WT mice that received control viral injection $(\mathrm{vWT}, n=12)$. $\boldsymbol{D}$, Percent responses made on the preferred lever during BP did not differ between groups. Percent preference $=$ no. of responses on preferred lever/total no. of responses on both levers. Preferred lever was defined as the lever that received the highest number of responses during the BP session (choice trials). $\boldsymbol{E}$, Percent food pellets consumed did not differ between groups (cumulative, Sessions $1-5$, and BP). ${ }^{*} p<0.05$ vs vWT.

\section{A}
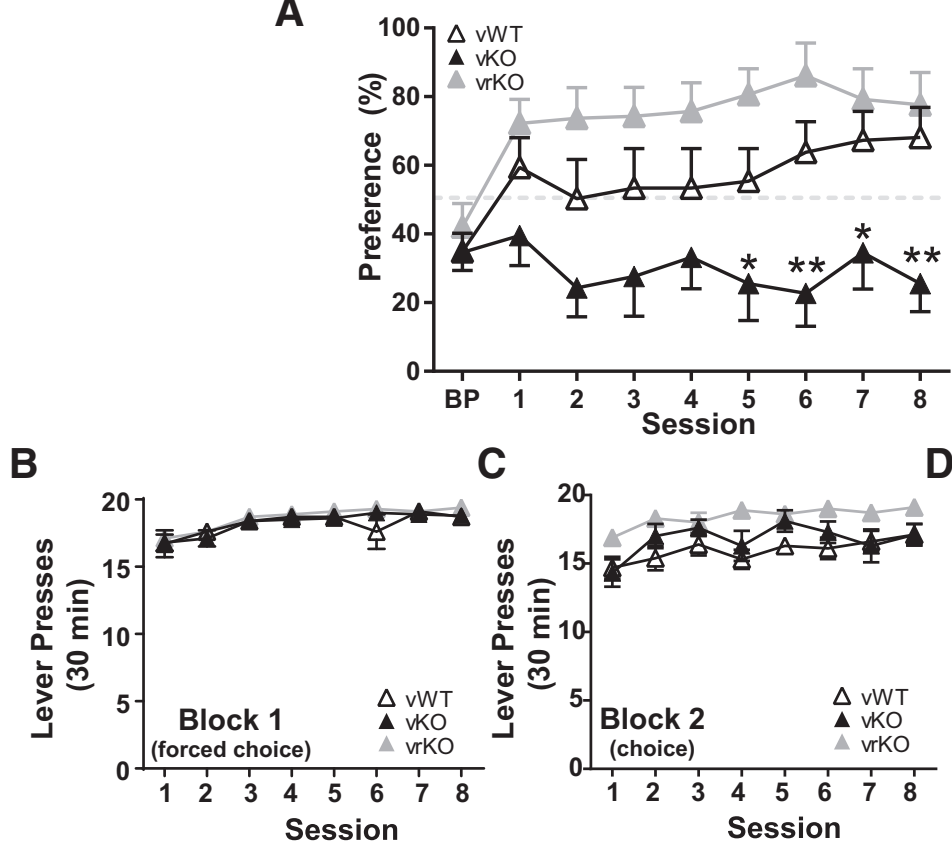

C
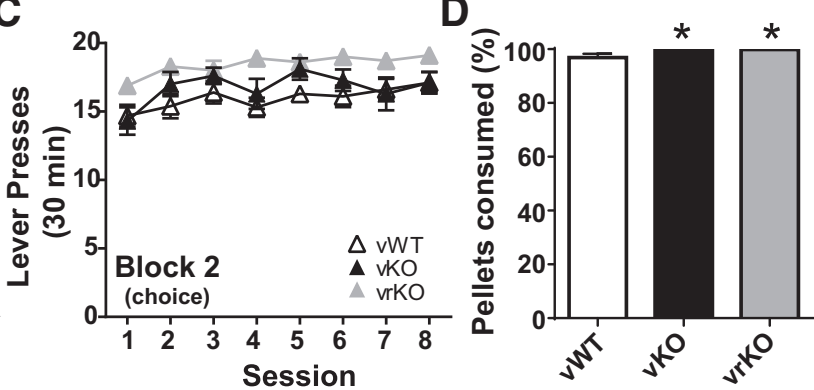

Figure 9. Viral restoration of GPR88 expression to the striatum restores reward density response discrimination in K0 mice. $A$, WT mice injected with control virus (vWT, $n=7$ ) and K0 mice with GPR88 expression virally restored to the striatum (vrK0, $n=7$ ) shifted responses to the high-reward ( 3 pellet) lever. K0 mice that received control virus (vK0, $n=8$ ) failed to acquire this choice profile. B, All groups completed similar training/no-choice trials (Block 1). C, vrKO mice completed more choice trials (Block 2) than control groups. D, K0 groups (vK0, vrK0) consumed more pellets than WT controls (vWT) (cumulative, days $1-8) .{ }^{*} p<0.05,{ }^{* *} p<0.01$ vs vWT.

man et al., 2016b). A recent report on conditional KO mice (GPR88-deficient D2 MSNs) demonstrated that hyperactivity was attributable to D2 pathway and hypersensitivity to novelty, D1 pathway (Meirsman et al., 2016b). Combined with previous work, our data suggest that GRP88 regulates both streams of striatal output.

Our results indicate that the striatum integrates homeostatic and motor information to prioritize and permit economical for- 
aging behavior (Salamone et al., 1994; Aberman et al., 1998). Furthermore, we demonstrate that striatal GPR88 participates in efficient selection of food-reinforced action. Humans carrying a mutation (premature stop codon) in GPR88 have also recently been identified (Alkufri et al., 2016). Whether these individuals also exhibit impaired discrimination between quantities (nutritional or monetary) will be an interesting direction for future research.

\section{References}

Aberman JE, Ward SJ, Salamone JD (1998) Effects of dopamine antagonists and accumbens dopamine depletions on time-constrained progressiveratio performance. Pharmacol Biochem Behav 61:341-348. CrossRef Medline

Alexander GE, Crutcher MD (1990) Functional architecture of basal ganglia circuits: neural substrates of parallel processing. Trends Neurosci 13:266-271. CrossRef Medline

Alkufri F, Shaag A, Abu-Libdeh B, Elpeleg O (2016) Deleterious mutation in GPR88 is associated with chorea, speech delay, and learning disabilities. Neurol Genet 2:e64. CrossRef Medline

Barry D, Petry NM (2008) Predictors of decision-making on the Iowa Gambling Task: independent effects of lifetime history of substance use disorders and performance on the Trail Making Test. Brain Cogn 66:243-252. CrossRef Medline

Bechara A, Damasio AR, Damasio H, Anderson SW (1994) Insensitivity to future consequences following damage to human prefrontal cortex. Cognition 50:7-15. CrossRef Medline

Bechara A, Dolan S, Denburg N, Hindes A, Anderson SW, Nathan PE (2001) Decision-making deficits, linked to a dysfunctional ventromedial prefrontal cortex, revealed in alcohol and stimulant abusers. Neuropsychologia 39:376-389. CrossRef Medline

Becker JA, Befort K, Blad C, Filliol D, Ghate A, Dembele D, Thibault C, Koch M, Muller J, Lardenois A, Poch O, Kieffer BL (2008) Transcriptome analysis identifies genes with enriched expression in the mouse central extended amygdala. Neuroscience 156:950-965. CrossRef Medline

Beeler JA, Daw N, Frazier CR, Zhuang X (2010) Tonic dopamine modulates exploitation of reward learning. Front Behav Neurosci 4:170. CrossRef Medline

Befort K, Filliol D, Ghate A, Darcq E, Matifas A, Muller J, Lardenois A, Thibault C, Dembele D, Le Merrer J, Becker JA, Poch O, Kieffer BL (2008) Mu-opioid receptor activation induces transcriptional plasticity in the central extended amygdala. Eur J Neurosci 27:2973-2984. CrossRef Medline

Buelow MT, Frakey LL, Grace J, Friedman JH (2014) The contribution of apathy and increased learning trials to risky decision-making in Parkinson's disease. Arch Clin Neuropsychol 29:100-109. CrossRef Medline

Cagniard B, Balsam PD, Brunner D, Zhuang X (2006) Mice with chronically elevated dopamine exhibit enhanced motivation, but not learning, for a food reward. Neuropsychopharmacology 31:1362-1370. CrossRef Medline

Carter ME, Soden ME, Zweifel LS, Palmiter RD (2013) Genetic identification of a neural circuit that suppresses appetite. Nature 503:111-114. CrossRef Medline

Caul WF, Brindle NA (2001) Schedule-dependent effects of haloperidol and amphetamine: multiple-schedule task shows within-subject effects. Pharmacol Biochem Behav 68:53-63. CrossRef Medline

Clark L, Iversen SD, Goodwin GM (2001) A neuropsychological investigation of prefrontal cortex involvement in acute mania. Am J Psychiatry 158:1605-1611. CrossRef Medline

Cui G, Jun SB, Jin X, Pham MD, Vogel SS, Lovinger DM, Costa RM (2013) Concurrent activation of striatal direct and indirect pathways during action initiation. Nature 494:238-242. CrossRef Medline

Denk F, Walton ME, Jennings KA, Sharp T, Rushworth MF, Bannerman DM (2005) Differential involvement of serotonin and dopamine systems in cost-benefit decisions about delay or effort. Psychopharmacology (Berl) 179:587-596. CrossRef Medline

Denny-Brown D, Yanagisawa N (1976) The role of the basal ganglia in the initiation of movement. Res Publ Assoc Res Nerv Ment Dis 55:115-149. Medline

Fiorillo CD, Tobler PN, Schultz W (2003) Discrete coding of reward probability and uncertainty by dopamine neurons. Science 299:1898-1902. CrossRef Medline
Fiorillo CD, Newsome WT, Schultz W (2008) The temporal precision of reward prediction in dopamine neurons. Nat Neurosci 11:966-973. CrossRef Medline

Font L, Mingote S, Farrar AM, Pereira M, Worden L, Stopper C, Port RG, Salamone JD (2008) Intra-accumbens injections of the adenosine A2A agonist CGS 21680 affect effort-related choice behavior in rats. Psychopharmacology (Berl) 199:515-526. CrossRef Medline

Gan JO, Walton ME, Phillips PE (2010) Dissociable cost and benefit encoding of future rewards by mesolimbic dopamine. Nat Neurosci 13:25-27. CrossRef Medline

Ghate A, Befort K, Becker JA, Filliol D, Bole-Feysot C, Demebele D, Jost B, Koch M, Kieffer BL (2007) Identification of novel striatal genes by expression profiling in adult mouse brain. Neuroscience 146:1182-1192. CrossRef Medline

Grant S, Contoreggi C, London ED (2000) Drug abusers show impaired performance in a laboratory test of decision making. Neuropsychologia 38:1180-1187. CrossRef Medline

Gurney K, Prescott TJ, Redgrave P (2001) A computational model of action selection in the basal ganglia: I. A new functional anatomy. Biol Cybern 84:401-410. CrossRef Medline

Hajnal A, Smith GP, Norgren R (2004) Oral sucrose stimulation increases accumbens dopamine in the rat. Am J Physiol Regul Integr Comp Physiol 286:R31-R37. CrossRef Medline

Hoover JE, Strick PL (1993) Multiple output channels in the basal ganglia. Science 259:819-821. CrossRef Medline

Houk JC, Bastianen C, Fansler D, Fishbach A, Fraser D, Reber PJ, Roy SA, Simo LS (2007) Action selection and refinement in subcortical loops through basal ganglia and cerebellum. Philos Trans R Soc Lond B Biol Sci 362:1573-1583. CrossRef Medline

Ingallinesi M, Le Bouil L, Biguet NF, Thi AD, Mannoury la Cour C, Millan MJ, Ravassard P, Mallet J, Meloni R (2015) Local inactivation of Gpr88 in the nucleus accumbens attenuates behavioral deficits elicited by the neonatal administration of phencyclidine in rats. Mol Psychiatry 20:951958. CrossRef Medline

Kelley AE (2004) Ventral striatal control of appetitive motivation: role in ingestive behavior and reward-related learning. Neurosci Biobehav Rev 27:765-776. CrossRef Medline

Kim H, Sul JH, Huh N, Lee D, Jung MW (2009) Role of striatum in updating values of chosen actions. J Neurosci 29:14701-14712. CrossRef Medline

Kobayashi S, Schultz W (2008) Influence of reward delays on responses of dopamine neurons. J Neurosci 28:7837-7846. CrossRef Medline

Kravitz AV, Freeze BS, Parker PR, Kay K, Thwin MT, Deisseroth K, Kreitzer AC (2010) Regulation of parkinsonian motor behaviours by optogenetic control of basal ganglia circuitry. Nature 466:622-626. CrossRef Medline

Logue SF, Grauer SM, Paulsen J, Graf R, Taylor N, Sung MA, Zhang L, Hughes Z, Pulito VL, Liu F, Rosenzweig-Lipson S, Brandon NJ, Marquis KL, Bates B, Pausch M (2009) The orphan GPCR, GPR88, modulates function of the striatal dopamine system: a possible therapeutic target for psychiatric disorders? Mol Cell Neurosci 42:438-447. CrossRef Medline

Malloy-Diniz L, Fuentes D, Leite WB, Correa H, Bechara A (2007) Impulsive behavior in adults with attention deficit/ hyperactivity disorder: characterization of attentional, motor and cognitive impulsiveness. J Int Neuropsychol Soc 13:693-698. CrossRef Medline

Massart R, Guilloux JP, Mignon V, Sokoloff P, Diaz J (2009) Striatal GPR88 expression is confined to the whole projection neuron population and is regulated by dopaminergic and glutamatergic afferents. Eur J Neurosci 30:397-414. CrossRef Medline

Massart R, Mignon V, Stanic J, Munoz-Tello P, Becker JA, Kieffer BL, Darmon M, Sokoloff P, Diaz J (2016) Developmental and adult expression patterns of the G-protein-coupled receptor GPR88 in the rat: establishment of a dual nuclear-cytoplasmic localization. J Comp Neurol 524: 2776-2802. CrossRef Medline

Meirsman AC, Robé A, de Kerchove d'Exaerde A, Kieffer BL (2016a) GPR88 in A2AR neurons enhance anxiety-like behaviors. eNeuro 3:ENEURO.0202-16. 2016. CrossRef Medline

Meirsman AC, Le Merrer J, Pellissier LP, Diaz J, Clesse D, Kieffer BL, Becker JA (2016b) Mice lacking GPR88 show motor deficit, improved spatial learning, and low anxiety reversed by delta opioid antagonist. Biol Psychiatry 79:917-927. CrossRef Medline

Mink JW (1996) The basal ganglia: focused selection and inhibition of competing motor programs. Prog Neurobiol 50:381-425. CrossRef Medline Mizushima K, Miyamoto Y, Tsukahara F, Hirai M, Sakaki Y, Ito T (2000) A 
novel G-protein-coupled receptor gene expressed in striatum. Genomics 69:314-321. CrossRef Medline

Norgren R, Hajnal A, Mungarndee SS (2006) Gustatory reward and the nucleus accumbens. Physiol Behav 89:531-535. CrossRef Medline

Parker NF, Cameron CM, Taliaferro JP, Lee J, Choi JY, Davidson TJ, Daw ND, Witten IB (2016) Reward and choice encoding in terminals of midbrain dopamine neurons depends on striatal target. Nat Neurosci 19:845854. CrossRef Medline

Quintana A, Sanz E, Wang W, Storey GP, Güler AD, Wanat MJ, Roller BA, La Torre A, Amieux PS, McKnight GS, Bamford NS, Palmiter RD (2012) Lack of GPR88 enhances medium spiny neuron activity and alters motorand cue-dependent behaviors. Nat Neurosci 15:1547-1555. CrossRef Medline

Redgrave P, Prescott TJ, Gurney K (1999) The basal ganglia: a vertebrate solution to the selection problem? Neuroscience 89:1009-1023. CrossRef Medline

Robinson S, Rainwater AJ, Hnasko TS, Palmiter RD (2007) Viral restoration of dopamine signaling to the dorsal striatum restores instrumental conditioning to dopamine-deficient mice. Psychopharmacology (Berl) 191: 567-578. CrossRef Medline

Roesch MR, Calu DJ, Schoenbaum G (2007) Dopamine neurons encode the better option in rats deciding between differently delayed or sized rewards. Nat Neurosci 10:1615-1624. CrossRef Medline

Salamone JD, Cousins MS, Bucher S (1994) Anhedonia or anergia? Effects of haloperidol and nucleus accumbens dopamine depletion on instrumental response selection in a T-maze cost/benefit procedure. Behav Brain Res 65:221-229. CrossRef Medline

Salamone JD, Wisniecki A, Carlson BB, Correa M (2001) Nucleus accumbens dopamine depletions make animals highly sensitive to high fixed ratio requirements but do not impair primary food reinforcement. Neuroscience 105:863-870. CrossRef Medline

Schultz W (2010) Dopamine signals for reward value and risk: basic and recent data. Behav Brain Funct 6:24. CrossRef Medline

Shurman B, Horan WP, Nuechterlein KH (2005) Schizophrenia patients demonstrate a distinctive pattern of decision-making impairment on the Iowa Gambling Task. Schizophr Res 72:215-224. CrossRef Medline
Stalnaker TA, Calhoon GG, Ogawa M, Roesch MR, Schoenbaum G (2010) Neural correlates of stimulus-response and response-outcome associations in dorsolateral versus dorsomedial striatum. Front Integr Neurosci 4:12. CrossRef Medline

Stout JC, Rodawalt WC, Siemers ER (2001) Risky decision making in Huntington's disease. J Int Neuropsychol Soc 7:92-101. CrossRef Medline

Struglia F, Stratta P, Gianfelice D, Pacifico R, Riccardi I, Rossi A (2011) Decision-making impairment in schizophrenia: relationships with positive symptomatology. Neurosci Lett 502:80-83. CrossRef Medline

Tecuapetla F, Jin X, Lima SQ, Costa RM (2016) Complementary contributions of striatal projection pathways to action initiation and execution. Cell 166:703-715. CrossRef Medline

Tobler PN, Fiorillo CD, Schultz W (2005) Adaptive coding of reward value by dopamine neurons. Science 307:1642-1645. CrossRef Medline

Van den Heuvel DM, Pasterkamp RJ (2008) Getting connected in the dopamine system. Prog Neurobiol 85:75-93. CrossRef Medline

Van Waes V, Tseng KY, Steiner H (2011) GPR88 - a putative signaling molecule predominantly expressed in the striatum: cellular localization and developmental regulation. Basal Ganglia 1:83-89. CrossRef Medline

Vicente AM, Galvão-Ferreira P, Tecuapetla F, Costa RM (2016) Direct and indirect dorsolateral striatum pathways reinforce different action strategies. Curr Biol 26:R267-R269. CrossRef Medline

Whitney KA, Fastenau PS, Evans JD, Lysaker PH (2004) Comparative neuropsychological function in obsessive-compulsive disorder and schizophrenia with and without obsessive-compulsive symptoms. Schizophr Res 69:75-83. CrossRef Medline

Young JW, van Enkhuizen J, Winstanley CA, Geyer MA (2011) Increased risk-taking behavior in dopamine transporter knockdown mice: further support for a mouse model of mania. J Psychopharmacol 25:934-943. CrossRef Medline

Zhang M, Kelley AE (2000) Enhanced intake of high-fat food following striatal mu-opioid stimulation: microinjection mapping and fos expression. Neuroscience 99:267-277. CrossRef Medline

Zhang M, Gosnell BA, Kelley AE (1998) Intake of high-fat food is selectively enhanced by mu opioid receptor stimulation within the nucleus accumbens. J Pharmacol Exp Ther 285:908-914. CrossRef Medline 